\title{
Christelike Teologie en Christelike Filosofie en Hulle Onderlinge Verhouding
}

\section{INIIEIIIING;}

Ons leef vandag in alle opsigte. maar ook in die wetenskap in die algemeen en in die teologie en filosofie in besonder, in in tyd waarin negatiewe aftakeling van alles wat tradisioneel en vas was. hoog in die mode is. Onder die skuilnaam van progressie. skep dit in toe. stand van oneindige verwarring en verwildering. sodat mens in die versocking kom om of saam amok te maak of om andersins na in veilige skuilplek te soek by een of ander gesaghebbende persoon of by een of ander kort en kraglige. maklik versiaanbare en hanteerbare formule of beginseluitspraak.

As gelowiges mag ons nie revolusionêr saam met die wêreld en sy ongelowiges en half gelowiges amok maak nie. Ons mag ons nie oorgee aan die wanhoopstemming van die Areopagus waarin niemand iets anders te doen het nie as on iets nuts te probeer sê fof publi. seer) of om iets nuts ie hoor (en te spploudiseer) nic. As ons waarlik in alles gehoorsam wil wees aan die Woord van God. moet ons hier ook uitgaan van die wadrheid vän I Joh. 2:7 en 8. nl. dat daar geen nuwe gebod is nic. mar slegs die one wat ons van die begin af gehad en gehoor het. wat $\log$ ook weer in nuwe gebod is. .. Wat waar is in Hom (Christus) en in julle. want die duisternis gaan verby en die waar. agtige lig skyn alreeds."

(Ons moet waak teen die uiteindelike steriliteit van vernuftige in. valle (wat soms in die vorm van interessante klein boekies in teologic en in filosofie ons vandag oorstroom). net soos teen die ..dorre doods. heid" van ..starre" menslike sisteme (waaraan die vaders glo so dikwels ...skukdig" was in hulle veclhandige summa ${ }^{3}$ ). ${ }^{1}$ Ons moet ontliou dat die suiwer (alvinistiese denke nog altyd op grond van die Skrif geken. merk was deur o.a. die beginsel van complexio oppositorium." en dal daar van min probleme in enkelvoudige. maklike oplossing bestaan. ()ns moet oppas dal die valse soeke na eenvoud ons nie verlei tot eenvoudigheid nie.?

Ons moet nie saam met baie mense in ons tyd die uetenskap as rodanig tot in selfstandige Mag verhef. hetsy uitgesproke of stil. swyend.' derhalwe ook sice die keologic of $/ \mathrm{en}$ filosolie nie. Wetenskap word beoefen deur me'ne' en dit is hulle wat vir goes of kudad verantwoordelik is. net $s$ is teolngie en filosofie die werk van mense. in concreto hier by ons nou die uerk van (liristenmense. Ons is ook hierin mekadr se broers en broeders en moet mekadr vertrou. Slegs op hierdic basis kan ons eerlik en vol verskil en mekaar reghelp en aanvul watar nolig. Al sou in man se stellinge lei of kan lei tol kellerye. dan mag en han ons hom nic inmiddelik lol die buitensle duisternis ver. doem nie: ook hier geld Mall. 18. 
Wetenskap mag geen afgod of dwingeland wees of word nie. maar dit mag ook nie verlaag word tot blote spel en nuttelose tydverdryf nie. Dit is deel van ons kultuurtaak en roeping en derlalwe hoegenaamd geen weelde nie. In ons problecm gaan dit finaliter ook oor die bestaan en voortbestaan al dan nie van die P.li. vir C.II.O., in kontrakteule verband met die Skool vall die Kerk (waardeur o.a. dic teologiese wetenskap gedoseer word gedeeltelik onder sorg en toesig van die Kerk.)

Christelike wetenskap as probleem en taak is die uileindelike basis van die onderlinge verhouding van Christelike teologie on Christelike filosofie. Hierby is wetenskapsleer, en daarin die logika, van deurslaggewende betekenis. Daar is vandag heelwat ..Christelike teo. logiee" en ,.Christelike filosofiec", wat verskillende standpunte hukdig en verkondig oor ons probleem. Daarby kom dat daar in die weten. skapsleer ook baie standpunte is en in die logika legio. Ook hier moel ons oppas dat ons nic eenvoudigheid openbaar deur bv. aan te neem dat daar net dié logika ván Âristoteles is nic."

In die algemeen-menslike neiging om menslike outoriteite te soek en aan te hang. is ons almal baie licf om sulke outoriteite to standardiseer, af te baken en as t ware in te $\mathbf{k}$, soos die moderne blikkieskos-industrie dit doen met vars voedsel. Allerlei handboeke versterk hierdie neiging om vir ons bv. "n pasklaar afgebakende outoriteit te gee, wie se wysheid ons kan aanhang en gebruik soos vandag se baie soorte pille, klaaraangemaakte medisynes vir allerlei kwale. So bestaan daar verskillende ingelegde Aristotelesse en Calvyns, ens., wat van pas en onvanpas so aangehdal en gebruik word. Hierteenoor het Vollenhoven bv. aangetoon dat daar drie verskillende onderskeie periodes en stadia in Aristoteles se werk en derike wiss. en sê (i. B. Kerford dat Aristoteles geen Aristoteles was nie, d.w.s. hy was nie wat sy volgelinge van hom gemaak het nie. So is daar ook die gevaar dat by noukeurige studie dit mag blyk dat Calvyn geen, Calvinis was nie.

Dit neem nie weg dat sulke manne tog sekere duidelike. vaste hoofgedagtes in hulle werk gelewer het nie. maar ons noem en bi klemtoon dit, nl. hierdie algemeen-menslike onafgerondheid van hulle werk. slegs om ons tot groot versigtigheid te maan wanneer ons ons op sulke manne beroep of hulle veroordeel.

In die Christelike wetenskapsbeoefening, in teologie en filosofie. kom ons in die eerste en laaste plek voor Cod self te staan. Daarom moet ons denke soos die van Anselmus', net 'n gebed begin. biddend voortgaan en met 'n gebed afsluit. (liteindelik gaan allcs primêr om ( $j(x)$ om gehoorsaamheid aan die eerste gebol"

A. .Skrifmagtige" filosofie en tenlogie.

- K. J. Popma en B. J. van der Walt

Die Wysbegeerte van die Wetsidee, wat die afgelope veertig jaar so sterk op die voorgrond getree het. word soms gestel as die belang. rikste konsekwent-Christelike wysbegeerte. Vanselfsprekend is daarin ook geweldig geworstel en hard en eerlik gewerk oor die probleen 
van die verhouding tussen Christelike wysbegcerte en Christelike teologie. Aanvanklik. en vandag nog. is deur baie mense aanvaar dat die wysbegeerte in die algemeen. wat van oorsprong heidens-Gricks was, vanself maar altyd heidens of halfheidens is en sal bly. en dus eenvou. dig taboe is vir die Christen. en so ook vir die Christen-wetenskaplike. Net so is en word ook nog deur baie aanvaar dat die teologie vanself. sprekend heilig en daarom Christelik is. en dus voldoende is vir die Christen-wetenskaplike. Noukeurige navorsing toon baie duidelik dat ons selfs by die heidense Grieke na naam en inhoud ook teologie kry. en omgekeerd het die ontwikkeling en uitbou van die Wysbegeerte van die Wetsidee (ons laat bv. Prof. H. (i. Stoker se Wysbegeerte van die Skeppingsidee en $\mathrm{H}$. Bavinck se Wyshegeerte van dic Openbaring hier voorlopig butte rekening) o.a. baie duidelik en volledig aangetoon dat 'n suiwer en konsekwente Christelike of Skrifnagtige wysbegeerte beslis moontlik is. M.a.w. die probleem is geensins Christelike teologie in sy verhouding tol heidense wysbigeerte nic. maar dic onderlinge verhouding van Christelike teologie en Christelike wysbegeerte tot mekaar. en so ook die verhouding van heidense teologie en heidense wyshegeerte tot mekaar. wat nie net by die Grieke en ander ou heidene voorkom nie. maar veelvuldig in die moderne en allermodernste tyd, juis ook in die sg. Christelike Weste.

Soos reeds gesê is hiercie probleen van dic verhouding van (Christelike teologie en Christclike wysbegeerte tot mekaar vir ons as Ciereformeerdes in S.A. nic net in teoretlese probieem. wat ons op sy kan skuif as ons wil nie. maar 'n daclikse praktiesc problecm. aan. gesien ons 'n P.U. vir C.II.O. het. waar albel op !lieselfue Calvinistiesc grondslag gedoseer word. waar die professore in die teologie finaliter kérkprofessore is en waar die kerk nog steeds so 'n sterk vertroue in die wysbegeerte alhier gehad het. dat bepaal is dat allc aspirantteoloë hulle propadeuse juis aan die P.l. vir ('.H.O. moet aflè. Die ou-nuwe Departement van Etiek en Logika. Wat tereg nou juis so sterk litgebou word. is hier ook op die spel. aangesien dit hier gaan om wetenskapsleer (logika) en lewens- en wêreldbeskouing (etiek). wat vir alle studente. ook aspirant-teoloè. verpligtend is. Bybelkunde kom ook hier ter sprake.

Netsoos daar baie soorte logika is en geen volladig-afgeronde Aristoteles of Calvyn nic. sc is ditar onk geen finaal en volledig afgeronde Wyshegeerte van die Wetsidee me. mar slegs $n$ groep Christen. wetenskaplikes wat hard en ywerig saamwerk op sekere min of meer algemene grondslae. maar wat onderling tog in baie ryke verskeidenheid vertoon. Ook hier mag ons dus nie sonder noukeurige studie heelhuids veroordeel of heelhuids aanvaar nie. allermins ten opsigte van ons probleem ter tafel. Hieroor is daar nog steeds 'n veclsydige debat binne die kringe van die Wysbegeerte van die Wetsidee a Hicrop kan en wil ons nic her ingaan nie. maar ons wil ons beperk tot die jongste werk in dié verband uit ons eie geledere. nl. B. J. van der Walt se M.A. (Filosofie)-verhandeling ..Dic Wysgerige kensepsie van Thomas van Aytuino in sy Summa contra (ientiles met sesiale ver. wysing na sy siening van leologic". Iehruarie 1968. (Ons bepaal ons 
by die eerste drie hoofstukke van die werk soos deur die I Iniversiteil aanvaar. Aangesien daar later nog 'n slothoofstuk moet bykom en dit nog nie voorhande is nie. en ons daarom nog nie die eie standpunt en konklusies van Van der Walt op skrif voor ons het nic. bepaal ons ons verder by die standpunt van K. J. Popma soos gegee in sy ..De Plaats der Theologie", 1946. Hoewel lg. reeds 'n betreklike ou werk is en 'n standpunt is waarin Popma self reeds verandering aangebring het." pas dit tog heeltemal vir ons doel, nl. on die konsekwensies van sekere grondbeginsels en -stellings, wat in hoofsaak deur al die manne van die Wysbegeerte van die Welsidee aanvaar word. vir die teologie en die ensikloperliese plek daarvan in die wetenskapsgebou. mooi duidelik te illustreer. Aangesien Van der Walt se werk nog nie gepub!iseer is nie en Popma s'n waarskynlik nie vir almal beskikbaar is nie. haal ons waar nodig volledig aan, en gee ons verder die standpunt. soos ons dit verstaan, stellinggewys, beginnende by Van der Walt. (Kursivering vi.n hom, tensy anders vermeld.)

\section{(a) (i) ,Warom die filosofie lan Thomas?"}

,Ons het hier met die grootste eksponent van 'n ware belangrike periode in die geskiedenis van die Westerse denke te doen. Thomas is ongetwyfeld een van die reuse uit die geskiedenis van die Wysbegeerte. Daarby die prominente verteenwoordiger van ' $n$ baie belangrike periode in dic geskiedenis van dic Filosofie, naam. lik die sintesetyd. Hierdie lydperk in die Westerse denke is nie alleen baie belangrik vir die Wysbegeerte self nie maar ook vir die Teologie, want ons (jereformeerde Tes)logie se historiese wor. tels lê ook in hierdie tydperk. Dit is n uiters belangrike periode vir onder andere Dogmageskierlenis, Kerkgeskiedenis, Apologetick. Kanoniek en die geskiedenis van die Eksegesa" -- p.l.

..n Laaste oorweging wat die keuse spesifiek op Thomas se filosofie laat val het, was die feit dat vandag allerwee dic aandag op sg. skolusriese reste in dic (jereformeerde Teologie en Wisho' geerte gevestig word by denkers soos o.a. A. Kuyper (sr.) en H. Bavinck. Besinning op die auctor primurius van die Skolastiek behoort dus die moeite werd te wees on tol groter helderheid in die verband te kom" - p. 2.

(ii).,Warom die besondere andag aan Thomas se siening lan Teologie?'

..Besinning oor die veld en grense vir die Teologic sal egter nic alleen vir die Teologie self nie. nuar ook vir die ander werenskaplpe vrugte afwerp. So mag dit byvoorbeeld lig werp op die verhouding tussen Teologie en Wysbegeerte. Bestudering van Thomas sal onder andere aantoon dat sy Teologie deurgaans deur wysgerige motiewe beheers word.

..Nadenke in verband met die Teologic is verder ook vir die nie-wetenskaplike terrein van belang. Ons het hier onder meer die verband tussen Teologe en die Woord van (iol, Teologic en belydenis, en Teologie en kerk. in gedagte" - p.3. 
(iii) ..Vir 'n Christelike wetenskap is dit eerstens nodig dat die kenner self Christen sal wees. Sy hart moct deur God gegryp wees en, in wederliefde tot Cod, streef om ook in sy kenaktiwiteit cod te dien en te gehoorsaam.

..Christelike wetenskap veronderstel verder dat die kenbare (of veld van ondersoek) deur die Woord var (iod verlig sal word" - p. 4 .

(iv) ..Die Bybel openbaar aan ons wal daar alles in en ook hoe die werklikheid is. Hierdie openbaring van (jod. wat ons in die geloof aanvaar, maak dit vir ons moontlik on 'n volledige en korrekte Filosofie oor die werklıkheid op te bou" - - p. 8.

(v)..Wat openbaar dic Woord van God nou aangaande die werklikheid?

Dit leer ons dat (jod Jaar is. dat Hy geskape het en dat Hy sy wet vir die skepping gestel het. Ons kan dus tussen die soewereine Cod. die vir die skepping geldende wet en die aan die wet onderworpe kosmos onderskei. (jod, wet en kosmos verskil radikaal van mekaar en die een mag nie tot die ander herlei of met die ander verwar word nie" - - p. 4.

..Die Woord van Cood openbaar nie alleen dat in die werklikheid tussen drieëlei syn onderskei moet word nie. maar werp ook nog verdere lig op elkeen van dic drie syne.

.Wat God betref. is dit anders gesteld as met die wet en die kosmos. By die wet en dic kosmos sprech ons van dic lig wat die Woord van (jod op hulle werp. (iokl is eg'er die onkenhure (kursivering van my, D.M.). Sy Woord werp nie net lig op Hom nie maar in sy Woord openbaar Hy Homselt aan ons. As ons die Woord van (jol nie gehad het nie. kon wel nog (gebrekkige) kennis van die wet en die kosmos gevind word. mar van (jod sou ons geen kennis gehad het nie.

..Daarom word in die Skrifmatige Wysbegeerte gelowig aanvaar wat ciod a angaande Homself in sy Woord openbaar. Daarby mag niks bygevoeg of daarvan mag niks weggelaat word nie. Die (icklsidee (kursivering van my. DM.) waarmee die Skrifmatige filosofie opereer, is nie deur ere wetenskaplike ondersoek daarge. stel nie. (jod kan nie die veld van ondersoek vir enige wetenskap wees nie. Die veld vir wetenskaplike ondersock is tol die wet en die kosmos beperk" - p. I0.

..Noge Gool self nogg sy Woord han veld van ondersoek vir enige wetenskap (ook nie vir die Teologie) wees nie. Wetenskaplike akliwiteit is 'n menslike aktiwiteit en tot die wet en die kosmos beperk" p. 11 .

.Volgens dic Woord kan hoofsaaklik tussen drieerlei gebruik van die woord . Wet onderskei word. nl. struktuurwet. liefdeswet en positiewe wet. Die eerste bepaal die struktuur van die bestaan van die dinge in die verskıllende ryke. Die tweede geld slegs vir die mens. Die derde ontstaan as die mens die liefueswet onder leiding van die betrokke (struktuur- of molale) wet vir die verskillende terreine van die menslike samelewing positiveer" .. p. 11. 
„Die probleem waar die wet presies gesoek moet word, naanlik in die skepping of bi dic skepping. is "n valse probleem. onldai 'n ruimtelike maatstaf dan op die wet toegepas word terwyl die ruimtelike alleein op die skepping van toepassing is. Al wat van die wet met betrekking tot die skepping gesê kan word. is dat dit vir die skepping geld. As ons in die bestudering van dic skepping sekere wetmatighede vind, beteken dit dus nie dat die wet nic van die skepping onderskei is nie. Tussen wetmagtigheid en wet is daar verskil. Wetmatigheid behoort wel to die skepping want dil is wat aan die maat(eis) van die wet beantwoord" (p. 11-12).

(vi) ..Verder onderskei die Skrifmatige Wysbegeerte tussen ver. skeie modaliteite of aspekte van die geskape worklikheid waarvan een die gelalaspek is. Eenheid en veelheid behooit alleen by hierdic éen aspek van dic geskape werklikheid tuis sodat dit cus nie verabsoluteer mag word nie. Dit mag in alle geva! glad nic op God of die wet van toepassing gemaak word nie. aangesicn dit alleen 'n kosmiese aspek is. Thomas maak dit byvoorheeld op (jol van toepassing as hy met die probleem' van die eenheid en di ie. heid van (jod worstel" - p.l6.

(vii) Onderskei dic universele en die wet. .. Dic universele is egter alleen van toepassing op die kosmos en nie op die wet of God nie."

„In Thomas se filosofie sal ons verder ook vind dat hy verkeerdelik die universele en indiwiduele aspekte van die skepping op Cod toepas. (jod is én as gevolg van Sy godwees. Sy ecn wese of wet (dic universele kant vin (jod). maar dric as gevolg van die feit dat $\mathrm{Hy}$ drie persone is (die indiwiduele kani van (jod)" p.20. .Persoon is 'n kosniese begrip. K. J. Popma sê lin sy verklaring van Sondag 18 van die Heidelbergse Kategismus): Als we zeggen, dat God Persoon is. lopen we enige gevalir dat we van dic hemelse majesteit Gods aards denken, vgl. antwoord 121. Beter waren te belijden dat God ondanks zijn persoonlijke bemoeieni. met mensen boven persocnzıjn vesheven blijft. . . . . Verder word ook die getalaspek van die skepping op riou vain roepassing gemaak deur van Hom as een of twee of drie te spreek. Dal dit foutief is om dit te doen, blyk reeds uit die woord .Drie-eenheid". Dit bots met die getalswette' -... in die skepping vind ons nèrens: iets wat terselfdertyd drie en een is nie. $1 G$ ol kan nie mar hierdic getalswette oortree nie -. $\mathrm{Hy}$ is nie daaraan onderworpe nic)" p. 186-7.

(viii) ..As Thomas met sy sintcsetilosofie na vore hom. het dis: sintesedenke egler al 'n lang weg afgelê. Die lydperk van die eerste sintese dolie vroeg-(hristelike denke vanaf ongeves 50 n.C tot die begin van die Middeleeue) is reeds verby. Dic (weede silitese het aangebreek (dic Middelecuse filosofie).

Tydens die periode van die eerste sintese het die sintese tussen die heidendon en dis Woord lan (iod nog in spontane karainter 
gedra. Die tweede sintese (watarbinne Thomas val) word egter gekenmerk deur die Skclastiek: Men bestudeert natuurlijk ook nog wel de Schrift. maar daarnáást ook de bocken van de vroegChristelijke denkers. En beide bewcrkt men dan op een schoolsc metode: vandaar de naam Scholastiek." "1

„Tereg sê J. Hessen: .Der mittclalterliche Mensch philosophiert darum stets im Aufblick zu Jeri Autoritäten. Seine Philosophic ist wesentlich Autoritätenphilosophie.'12 p. 45.

(ix)..Ons het reeds voorheen aangctoon dat Thomas ook die geloof (wat 'n bo-natuurlike genadegesienk van God is) as ken. fakulitcit sien" - p. 108.

(x) ..Dat Aristoteles se Teologie Thomas se bonatuurlike Teologie word. blyk ook dadruit dat Arsstoteles sy Teologie koningin van die wetenskappe noem ${ }^{25}$ en Thomas hierdie eer nie aan sy natuurlike maar alleen aan sy honatuurlike Teologie laat toekom" p. 130 .

(xi) ..Thonas omskryf die kennis wat sy natuurlike Teologie bied as .truth which faith professes and Icason investigates." Dit is moontlik volgens Thomas se besondere siening van geloof en wete. Die geloof bevestig die wele en die wete bevestig die geloof. In die natuurlike Teologie kan dus ook uitsprake van die Woord van God (iets wat tot die gebied van die geloof behoort) aangehaal word ter bevestiging van wat die rede op die gebied van die natuur vind. (Netsoos wat in die bonatuurlike Teologie teruggegryp kan word na die resultate wat met die rede gevind is.)" - p. 131 .

(xii) ,Op die gebied van die geloof kry ons (by Thomas) in bonatuurlike verligting (netsoos wat ons by die rede 'n natuurlike verligting gevind het) wat dit moontlik maak om die Openbaring te gryp" - p. 133.

(xiii) In hierdie verband moet weer die aanleiding to die skiyf van die Contra (ientiles in gedagte gehou word. Thomas skryf die werk op versoek van sendelinge om hullc in staat te stel on die Mohammedane $10 t$ die (hristelike geloof te oorreed. Dit kan (volgens hom) alleen of redelike vlak geskied - p. 139. (kursivering van my. DM.)

Tog se Thomas ook: .. The sole way to overcome an adversary of divine truth is from the authority of Seripture - an authority divinely confirmed by miracles. For that which is above the human reason we believe only because (joxl has revealed it. Nevertheless. there are certain likely arguments that shouk! be brought forth in order to make divine truth known. I his should be done for the training and consolation of the faithful, and not with ainy idea of refuting those who are adversaries" - p. 14(1).141.

(xiv) .. . . . na.ımlık dat dic bonatuurlıke Teologie. howel dit op die lerrein van dic geloof $k$. ook in wetenskap (scientia) 
is. Daarom is die sacra doctrina vir Thomas (behalwe praktics) ook spekulatief van dard. . Ons het gesien dat Thomas se spekulatiewe wetenskappe die wetenskappe is war kennis met die rede verkry word" -- p. 143-144.

(xv) ,.Ons het reeds gesien dat Thonsas sy bonatuurlike Teologic Christelike Teologie noem. In die Summa Theologica spreek hy selfs daarvan as heilige (sacra doctrina). Sover ons kon nagaan sê Thomas nie waarom hy hierdie wetenskap as (vanselfsprekend) Christelik en heilig beskou nie. Blykbaar is dit as gevolg van die veld van ondersoek. naamlik God en Sy Woord.

..Dit blyk ook verder dat dit die enigste (hristelike wetenskap is wat Thomas erken. Hy dui gcen onder wetenskap - selfs nic eers die natuurlike Teologie - as (hristelike aun nic" - p. 147

(xvi) ..E. Caird: Scholastic theology reaily deserves the character which Mommsen has attributed to all theology: it is the bastard of faith and reason.' (Noot 17 by Hf. III. p. 394.)

(xvii) ,Elders sê hy (Dooyewcerd) van Thomas se natuurlike Teologie: ..Dat zij inderda de een dosmanische schim-wetenschap is, niet hierom wijl ze door religieuse vooroordeelen is bepaald, maar omdat zij haar religieuze voor-oordeelen voor zuiwer theoretische axiomas uitgeeft en eigenlijk niets anders Joet dan in den vorm van een logische hewijs hadr aproristische ootsprongsidee te ex. pliceeren. die reeds implicite vervat was in de tot theoretische axiomas verheven gromlslagen der bewijsvoering"." p. 149.

(b) Die skerp stelling van Van der Walt ..God is die onkenbare" soos aangehaal onder 12 (v) hierbo, word duideliker as ons dit aanvul uit die gedagtegang van sy leier by die opstel van die verhandeling Prof. J. A. I. Taljaard. Ons gee die volgende aanhalings ${ }^{5}$ volledig ondat. hoewel Taljaard hier hoegenaand niks sê van die teologie nie. die wortel en grondslag van die hele onderhawige heskoning vail die Skrifmatige filosofie oor die tersogie hier baie duidelik en volledig gegee word. (Kursivering van my .D.M.)

(i)..Kennis en kenbaarheid is respektiewelik identies aan onderskeiding en onderskeihaurheid. (Onderskejbatarheid is in aspek van die aardsgeskape subjek: aan die diere in die paradys kon name gegee word omdat die diere benoembaar was en hierdie benoem. baarheid van die verskillende dierc onderskeihuar was. As onder. skeibaarheid wel 'n eienskap van die aardse skepping is. dan moet ons die radikale verskil tussen (iod en sy skepping handhad. Walt inhou dat riks van die Shepping aan die Skepper toegeskryf mag word nie. Vandaar ons standpunt dat (jod ook nie deel het dan die onderskeibaarheid wat tipies aards is nie. Dit steni ook ooreen met die Skrif: (jod is clic Onsienlike, die Verborgene. dic Onkenhare. (Ons eerste begrensing vanuit dié kenbare lê t.o.v. die Onkenbare. nl. God. Alle denksisteme wat (inal verlaag tol die kenbare en sodoende die grense vall die kenbare withrei. moet noolwendig verval in spekulasie. 
(ii) , Tog hou God homself nic verborge nie. Hy stel Homself bekend aan die mens. . Openbaring. Omdat daar in radikale verskil tussen God en mens is, daaron is daar ook 'n radikale verskil tussen die openharing lan $G(x)$ en die kenaklnwiteit van die mens... God openbaar... deur miduel van Woord en natuur... Die mens moet hom vergewis van die openbaringsinhoud ... Wat vir ons van belang̣ is, is juis die begrensing vanuit die kenbare teenoor die openbaringsinlioud en in besonder die Skrif. Dit kom van die Onkenhare, ral dus nie onder die kenhare nie en mag nooit tot die kenbare gedegradeer word nie . . anders ... spekulasie. Die Woord van God is die Waarheid. Die wetenskan soek na warheid en kan dus nic soek na die waarheid van dic Waarheid nie. Dit sou 'n vraagteken agter God en Sy Woord plaas. Vandaar ons oortuiging dat die Woord van God verhef is ho alle wetenskaplike ondersoek. $M_{y}$ kennis van die openbaringsinhoud en my interpretasie van die geopenbaarde waarheid kan ek egter alan wetenskaphke ondersoek onderwerp ... deel van die kenbare."

.. Ons moet wel weet wat die inhoud van hierdie openbaring is, waardeur Skriflesing die belangrikste in die menslike lewe be. hoort te wees. Maar nie slegs deur Skriflesing kry ons hiervan te wete nie-cok deur ons opvoedıng. die verkondiging. ens" - p. 659.

..Openbaring impliseer " $"$ bekendstelling. " $n$ ontvange van dit wat bekend gestel word. dus geen akriwiteit aan die kant van die ontvanger van die geopenbaarde nie ${ }^{-}-$p. 658 .

(iii) Dic verbondsrelasie as religie behoort ook nic tot dic terrein van dic kenbare nıe. So cok die liefdesgebod. Die kenriis wat ons hiervan besit is voor-wetenskaplik en berus op die geopenbaarde waarhed - p. 660).

(iv) Wetenskap is deel van die kultuur en nie-wetenskaplike kemis is natuurlik (p. 667). Natuurlike kemmis kan uitgebou word. Dit is ook 'n kultuuraktiwiteit. maar dit maak dit nog nie wetenskaplike kennis nie. Wetenskaplike kennis is besonder gekarakteriseerde kultuuraktiwiteite p. 607.

(v) In alle kennis (nie net die wetenskaplike nie. soos Dooyeweerd dit stel) is dic ontiese derhalwe verteoretiseer. Natuur en kultuur staan vertikaal langs mekaar -... p. 666.

(vi),.Die Wysbegeerte $k$ walifiseer as in nie-vakwetenskaplike wetenskap juis ondat in die Wysbegeerte die veld van ondersoek die samehang van alle verskeidenheid is. Ook die veld van ondersock vir die wysgeer is anders as vir die naluurlike lewens. en wereldheskouing" - p. 672-(173.

\section{(c) Same'varting:}

.. Teologie is die wetenskap wat tot voorwerp van ondersoek het die hemnis van (jokl. Wat deur die besondere openbaring. die Woord van (iol. tot ons gekom het." Met hierdie definisic sluit S.C.W. Duve. nage'" ten nouste aan by die tradlisioncle (iereformeerde opvalting van 
wat teologie eintlik is. In aansluiting by hierdic tradisie kom H. (i. Stoker tot twee nie-vakwetenskaplike algemene wetenskappe. nl. teolo. gie en wysbegeerte. elk met 'n eie blikrigting. in onderskeiding van die vakwetenskappe en ander mocnllike nie-vakwclenskaplike wetenskappc soos bv. die opvoedkunde. ${ }^{17}$

Hierteenoor kom nou o.a. Popma in 1946 to die konklusie dat die teologie slegs geloofsteorie kan wees, wat hy in clk geval baic skerp onderskei van die bekende normlose godsdienswetenskap."

Almal aunvar die Skrif omvoorwardelik as die Woord ran God Dit mag ons nooit uit die oog verloor nie Daarvoor moet ons God steeds dank, en dan dankend en biddend verder arbei on die geweldige verskille wat daar wel onder die Skrifgelowiges bestaan uit te pluis $\mathrm{cn}$. as dit moontlik is, op te los. Dit sal hoegenaamd nie maklik gaan nic. want wat die een aanvaar. verwerp die ander totaal.

Almal aanvaar op gronu van hulle Shrifgeloof in Calvinisticsc lewens- en wêreldbeskouing en bewus of onbewus. utgewerk of onuitgewerk, een of ander wetenskapsleer. wat dialrop gebaseei is.

Almal aanvaar hierdie lewens- en wereldbeskouing as voor- of nie-wetenskaplik. Almal aanvaar lat hierdic voor- of nie-wetenskaplite .naiewe" of ".natuurlike" keirnis nie as minderwaardlg teenoor wetenskaplike kennis gesien en gestel most word nie. Hieronder. d.w.s. onder die voor-wetenskaplike, val ook die belydenss van die kerk. wat ook deur almal onvoorwaardelik aanvaar word. hoewcl van dic kant van die Wysbegeerte van die Wetsidee soms oor dic uitdrukkingswyse var. die konfessie twyfel uitgespreek word. bv. Popma oor ..persoon" en van der Walt oor die terme van die ..Dric-Eenheid."

Op grond van sy kennsopvatting $k$ om Taljaard daartoe dat (ioxl en die Skrif tot die onkenbare behoort en dus nie wetenskaplik verwerk kan en mag word nie. Hierin volg Van der Walt hom, sodal daarmce die tradisioneel-aanvaarde velde of veld van ondersoek van die teologie: $c$ wetenskap. nl. kennis van (iod insover as wat Hy Hon geopenbaar het en daarmee kennis van sy Woord, wegval. Hulle handhauf die Woord van God ten volle. muar lan net as norm van die menslik wetenskaplike arbeid, nie as veld van ondersock nie. (Op grond van hierdie standpunt kan die teologie onmountlik koningin van die wetenskappe wees. soos bv. Thomas op die voetspoor van Aristoteles aanvaar het. Dit kan ook nie n algemene, nie-vakwetenskaplike wetenskap wees soos Stoker dit stel nie. maar slegs een van dis vakwetenskappc. wat deur die filosofie afgebaken moci word en sy plek gegee moet word. Hierdie vakwetenskap handel nie oor (jod of Sy Woord nic. maar slegs oor ons kennis en interprelasie daurian. ()or wat dit presies is en wat dit insluit. bestaan daar baie verskil. ook by lie manne van die Wysbegeerte van die Wetsidee onderling. Daarop gaan ons nie hier in nie. maar slegs op bg. grondverskil. en hiermee saam op die stelling van Van der Walt dat die Skolastiek van Thomas dic oorsprong en rede is dat die tradisionele opvatting van dic veld vall ondersoek van die teologie so verkeerd is. Dil is spekulatief. d.w.s. grens-oor. skrydende denke, soos Taljaard dil stel. Popma laat hom baic skerp) 
uit oor hierdic grens-oorskrydende en tirannicke teologie. wat soveel kwad vir en in die kerk gestig het en nog steeds aanrig.

Vanuit hecltemal 'n ander hoek kom die moderne teologie ook met die beswaar teen die skolastiek en alle vorme van metafisika. (Op hierdic punt spreek S. du loit. kan ons sê. numens die liele. of byna die hele. moderne teologic as hy waarsku teen die skolastiek." $O p$ dié punt staan hy en Van der Wa!t honderd persent saam. Albei wil die teologie verlos van die skolastick en sy metafisika.

Voordat ons hierdie sake krities ontleed en bespreek, wil ons dan cers vir ons rekenskap gee van die moderne teologie en die nood van die moderne mens in sy tyd. want. soos reeds gesê. is die bepaling van die verhouding van Christelike teologie en Christelike. meer spesifiek nog: Gereformeerde. filosofic vir die (iereformeerdes, van beslissen je lewensbelang - hier in S.A. en ook in Nederland. o.a. aan die Vrye Iniversiteit. en wel in verband met ons taak en roeping in die moderne wêreld. S. du Toit stel dit baie niooi en duidelik: .. Indien die Gereformeerde teologie werklik in geluid van betekenis wil lat hoor in in tyd van sekularisme sal dit gejurig op sy hoade moet wees i ir skolastiese elemente in sy erfenis en op voetspor valı die Reformatore soek na die .Schriftbeginselen ter Schriftverklaring (Greydanus). om dan na grondige eksegese die ewige e'angelie' te bring aan 'n wêreld wat siek en vermoeid is." "l"

\section{B. DIE MODERNE TEOIO(GIE EN DIE MODERNE WEREID IN SY NOOD.}

Voordat ons kan ingaan op die vraag of die Wysbegeerte van die Wetsidee se opvalting oor die teologie vandag ons probleme gaan oplos of nie. wil ons kortliks stilstuan by drie groepe verklarings oor die molerne tyd, nl.

(i) uit die sendingwêreld.

(ii) uit die natuurwetenskaplike wéreld. en

(iii) uit die teologiese wéreld self.

(i) Uit die Sendingwereld

Dr. (j. H. Roux was in 1967 reeds 18 jaar sendinggeneesheer onder die Bakgatlastam en aanverwante Tswanasprekende stamme. $\mathrm{Hy}_{\mathrm{y}}$ verwag net kwaad van die Wysbegeerte van die Wetsidee en veral van die gedagte van verwerpmng van alle melafisika. Hy noem dit on. tologie en skryf soos volg:" . Die (hristelike go:lsdiens op sigself het in sy beskawingsopset in feitlik onmoontlike taak daarin dat geloof staan teenoor geloof. Welisudar het dic (hristelike geloof sy positiewe voordele bo in geordende heidense uangeloof. maar dan konfronteer die Christelike geloof nog altyd by die Bantoc' 'n geintegreerde religcic en filosofie en wetenskap. $m$ a.w in totaalniens in sy omgewing en geskiedenis en eksistensie" $n$. 42.

.. . . ons wil in verantwoordelike eksistensic preck sonder die rugsteun van "n gesonde ontologie" $r$. 40.

..Die Wysbegeerte van die Wetsidee benader realiteit met in horde van synsanalogiee, die moreel-religieuse steriliteit, waarvan eers ten 
volle besef word indien gekonfronteer met die konkrete situasic van die kerstening van die elementêre heiden." .Goddank dat die behou. dende N.G. Kerk in Suidelike Afrika nog relatief afwerend staan teenoor hierdie ultra-moderne kultureelreligieuse strominge" $p .46$.

..Ons kan dit nie sterk genoeg beklemtoon dat die ewige en abso. lute kontras tussen God en skepsel nie lê op ontologiese vlak nie. maar wel op die eksistensieele. God is die Ewig-Onveranderlike: die skepsel word . . . Daar is 'n ewig absolute verskil ook op ontologiese vlak. maar dié lê nie tussen God en skepsel nie. maar tusien gees en stof tussen die positiewe en die negatiewe synsmatigheid" p. 41 . Hier is Roux nou baie naby aan. indien ne op. die dualistiese kosmologie van Thomas, soos Van der Walt dit stel.

Roux is uniek in sy standpunt. vanuit die sending. oor die Wysbe. geerte van die Wetsidee, moontlik omdat hy cen van dic weinige sendingmanne is wat dit kell. $\mathrm{H}_{y}$ is egter geen stem roepende in die woestyn in die sendingwêreld as dit gaan oor die behoefte aan meer suiwere teologie. Waar die kreet en mode vroeër in die sendingwêreld was: „'n minimum van teologie"'" daar vind ons nou dikwels die tecn. oorgestelde, soos ek self o.a. al probeer aantoon het."- Ons haal hicr drie manne aan: H. Kraemer skryf: .. The maxim is that a sound theoretical idea (or a sound theological conception) is not simply a matter of intellectual delight and enjoyment but rather the most practical thing in the world. This indissoluble oneness of clear lhought with vigourous action belongs to the essence of true theology. especially in relation to the Church's missionary calling." tyd met die eerste vier eeue na Christus, o.a. ook in die besinning op die Drie-Eenheid van God.:-

Moet hierdie noolsaaklike besinning oor die teologie op die voetspoor van Thomas gaan of moe! dit modern-antimetafisies wees?

J. E. L. Newbigin sê::- .Thus even in tts most elementary form the preaching of the Gospel must presuppose an understanding of the triune nature of God. It is not, as we have sometimes seemed to say. a kind of intellectual cap-stone which can be put on top of the arch at the very end; it is, on the contrary, what Athanasius called it. the arché, the presupposition without which the preaching of the cospel in a pagan world cannot begin."

Moet hierdie besinning oor die Trinitas nou beperk bly tot die voor-wetenskaplike lewens- en wêreldbeskouing wat op die Bybel gefundeer is, of moet dit, soos tradisioneel die geval was. eintlik dic kern van die teologiese wetenskap vorm?

\section{(ii) Uit die Natuurwelenskuplike wêreld}

Hier beperk ons ons tot éẻn persoon. wat seker, tenminste in Suid. Afrika, die reg het om namens die natuurwetenskaplikes te praat. Dit is Dr. S. M. Naude in sy voorsittersrede tydens die jaarlikse vergade. ring van die S.A. Akademie vir Wetenskap en Kuns te Blnemfontein op 26 Junie 1968: ${ }^{*}$ Hy wys daarop dat mens geneig is om die natuur. wetenskap te sien as 'n reeks verrassende en briljante ontdekkings. Ler. wyl baie van hierdie ontdekkings moontlik gemaak is deur en dic vrug 
is van sekere beskouinge oor dic naluur. Hy deel die ontwikkeling van die natuurbeskouing van die mens in drie stadia in:

(a) Die animistiese en gcosentricse stadium. tot ongeveer $15(x)$ n.C.:

(b) die meganiese stadium. vanaf $150(0)$ tot 1900) n.C.:

(c) die matemaliese stadium vanaf 1900 .

Hieruit sien ons ook dat die natuurwetenskap nie 'n homogene geheel is nie. maar dat ook hier 'n veelheid van standpunte en bc. skouinge in die loop van die eeue na vore gckom hel. Die nuutste ont. wikkeling berus op uitbreiding van die abstrakte denkwyse. Dit wek geesdrif wat lei ttot nuwe ontdekkings en verhoog steeds die eerbiad vir die Skepper. ..Die fistese wetenskap vereis dis aarname van in reële. van ons onafhanklike wêreld. wat ons egter nooit direk kon aanskou nie. maar slegs deur metings. wat ons met die loop van die tyd leer maak en interpreteer het. kan warneem en verklaar" p. 41. . Tot die eintlike wese van die heclal dring hy (die mens) nooit deur nie" - hy kom steeds meer en meer tot die hescf van die grootste wonder en van die Almag van die Skepper.

Dit lyk of Naude hier tog weer soek na in ontologie of metafisika al is dit hoegenaamd nie in Aristoteirese sin nie. en dat die God wat dood geraak het vir die teoloe besig is om op te staan by die natuurwetenskaplikes Die vraag bly dan nou net of dié Ged net vour. wetenskaplik geken kan word. en of $\mathrm{Hy}$ ook in sy openbaring wetenskaplik bestudeer kan word. In elk geval is dit baie duidelik dal n natuurwetenskaplike soos Dr. Naude. hoegenaamd nie so gesekulari. seerd is as die sg. moderne mens in die algemeen nic. d.w.s. volgens die moderne teoloë e.a. Hier mise ons seker buie Juidelik en skerp onderskei tussen die uitwerking van iie navorsing op die weten. skaplike self. nl. eerbied en verwondering. soos Naude 'it stel. en dic uitwerking van die sg. populêre netciskip op die gewone mens. nl. sekularisering en profanering van alles wat heilig is. Volgens (i. H. Roux is die Bantoe ook glad nie so gesekularisecrd as wat ons dink nie.

(iii) Uir die reologiese wereld self

Ons sluit hier aan by die reedsgenoemde artikel van Prof. S. du Toit" en verder by ..Revolle in de Theologie. Een bundel beschou. wingen over de zogenaamde vernieuwingstheologie onder redactie van Prof. Dr. (3. C. Berkiuwer en Prol. Dr. A. S. van der Woude."

Ons noem die verskillende skrywers hier on haal uit hulle artikels aan wat van belang vir ons onderwerp is.

(a) (;. F. Menlemum: Vernienwing in de Theologie

Ons het hier te doen met ..het denken in dienst", "n vertolking van die livangelie vir die modeine mens. p.9. ..Als taak van de dogmatiek ziet men dan de veltolking van die werklijkheid in verband met de situatie van de tijd " ${ }^{-}$p. 15. .. De openharing Goils niet moet worden opgeval als een geheel van geopenbaarde leerstellingen. doch allereerst als een in Christus meegeleede 
werkelijkheid." Teologie en wystegeerte word anders gesien as ..in de concluderend speculatiave theolngie van vioeger."

(b) G. C. V. Niftrik: Theologische Revolle

.Hij (God) begon al dood te gaan. toen Kant in de Kririk der reinen Vernunft de traditionele Godsbewijzen onver wierp" p. 22. ..Das ding an sich is niet te kennen; zeker niet das Ding an sich. Gol is een postilaat der praklische Vernunft." Dit gaan daaron ..om het extentieele te reciden" p. 25. ..De eigen existentie van de mens als de door Goci aangcraakte en aangesprokene is de modus waarin ik alleen over God spreken kan." . . . Existentic is een streng anihropologisch begrip" p. 23. Volgens Bultman is openbaring ontmoeting. p. 24.

(c) H. M. Kuitert: Niet-Iheologisch achtergronden lan de zg. Verniewingstheologie

Die groot gedagte is .. Wij zijn er ook nog" p. 33. . . .dat eigentijdse krijgt in de zg. vernieuwingstheologic een kans" p. 35. Die teologiese modelle moet verander ip. 40.41). (Ons het te doen met die druk van natuurwetenschaplike werklikheidsbegrip, p. $43 . .$. . . een happening veronderstelt een wereld die predictable is . . p. 44 . Nuwe dogmatiese vormgewing is nodig. p. 46.

(d) J. S .Weiland: De angelsaksische vernienwingstheologie.

Die teologic het telkens in anter filosofie tectioor sig. In Europa is dit die eksistensialisme en fenomenologie, in die Angtlsaksiese wêreld is dıt neo-positıvisme en .linguistic analysis" p. 49.

(e) H. (;. Hubheling: Anal:tische filosofic en theologit'.

Die analitiese filosofic baseer sig op linguistiese en logiese analise. p. 63: ..Deze wat losse, onsystematische behandeling is overigens wel in de lijn val! deze filosofie. ondat men hier systeembouw zeer vreest en steik genijgd is elk probleem apart te beschouwen en op zijn eigen facelten to beoordelen" $p .63$ Geen wetenskaplike en geen menslike aktiwiteit is moontlik sonder om taal en logika te veronderstel nie - p. 64 Dic logiese positivisme is meer eksterne vlcuel van die analitiese filosofie. Dit is lewensbeskoulik neutraal -- p. 65 en 70 . Teologie veronderstle logiese en linguistiese analise, die Bybel en die teologic is nic a- of antilogies nie, p. 65. Dit is geen smpiricse wetenskap nie en daar is steeds 'n bepalue metodiese beperking. p. 66. " Tualspel is 'n eenheid van gedagtes en begrippe wat op sekere aanvaarde aksiomata berus. Flke taalspel het so sy cie vocabu. larium. Daar kan 'n oneindige aantal taalspele wees. Elkeen is absoluut waar binne sy ele grense. Die wetenskaplike taak is om te soek na 'n optimale ordening var' elementêre uitsprake. .die ordening waarbij een maximum aan elementaire uitspraken wordt geordend met een minimum van ordeningsprincipes. terwijl 
de afleiding van de elementaire uitspraken uit de ordeningsprincipes zo cenvoudig mogelik dient te geschieden" .. p. 68 . .maar uiteindelik beslist de analytische filosofie niet over de criteria van een taalspel. Dit doen de spelers zelf" p. 69. Gods. dienstige en eliese uitsprake is me kognitief nie. maar emosioneel. p. 70. Hare stel dat godsdienstige uitsprake te doen het met in fundamentele grondhouding van die mens, .die niet meer em. pirisch te weerleggen of te verifieüren is" $\mathrm{p}$. 71. ..Het gelouf heeft voor de discipelen het karakter van een blik: het is geen theoretische waarheid. maar een .conmitment" ... p. 71.

Wittgenstein erken ook die onuitspreeklike, dic mistiese. p. 73.

(f) $M$. de Jonge: Theologie als /lermeneuriek

Ons moet onderskei tussen ou en nuwe hermeneutiek. Waar eg. na ..Voraussetzungslosigkeit" gestreef het en die subjektiviteit soveel moontlik wou uitskakel. daar laat die moderne sig tue. spreek of aanspreek. ..Wie zicn wel wil laten gezeggen, zal ook gedrongen worden on te getuigen ..." p. 75.

Volgens De Ionge wil Bultmann hê dat ons noet probeer om agter die woorde te kom. ..ondat de taal als zodanig objectiveert en daarmee het wezerlijke verduistert" p. 16 . Volgens hom is Eheling en Fuchs se standpunt soos volg te stel: ..Het is niet de mens. die zichzelf in woorden uitdrukt. maar de taal zelf spreekt en de zaak die in de taal ter sprake komt is het zijn zelf. Wezenlijk voor de mens is. dat hij de roep van het zijn hoort en dat hij met zijn woorden antwoordt op wat hem in de taal wordt aangezegd. Dat heeft als herrieneutische conse. quentic. dat men in menselijke woorden van de tekst luistert naar het zijn dat daarin ter sprake komi" p. 76. .. Het is het wezen en de glorie van de mens. dat hij dit spreken kan horen en door kan geven: en als hij luistert en spreekt. dan is het eigenlijk niet hij. die de tekst uitlegt. maar de tekst die hem uitlegl" p. 76-77. .. Uitleggen van een tekst uit het verleden houdt dan in. dat ment in de oude woorden Gods reddende Woord voor het heden nicuw latat spreken" p. 77. Spreke bevry. Heidegger sê: ...Sprache ist lichtend - verbergende Ankunft des Seins selbst ..." p. 77

Teologie is 'n tadbeweging p. 78 cn hermeneutiek die hern van filosofie en teologie. p. 79.

\section{(g) II. Berkof: De heilshist rische Theologie}

Die Israclitiese denke lâ tussen die wysgerig-idealistiese intorpretasic van geloof by links. en die skolastiese by regs. ..die beiden worden herleid tol een statisch-grieks denken" p. 90). Dit gaan om die dade van (iod. Sy handel in lyd en nie om sy ewige wese nic. On feite en nie on dogma's nie.

Pannenbery si die (hristendom is die historiese antwoord aan die (iricke. ()penbaring is nic bo.natuurlik nic. .. (ieloof berust dus op een voorafgiand weten dat doer het geloof peisoonlijh in ver. 
trouwen en hoop wordt toegeëigend . . " Die nie-gelowige is bevange, p. 96.

Berkof wys daarop dat Pannenberg vanweë hierdic opvattinge van hom verwyt word dat hy as gelowige hom vasklem aan feite. wat hy as man van die wetenskap weet is nie waar nic.

(h) II. A. M. Hislet: Vaticamm II als aitgangspamt van een vernieuwde geloofsbezinning

Die bekommernis van die moderne mens is 'n goeie teken. ..Deze schizofrene van hel essentialistisch denken" het die Christene verdeel: ..Geinspireerd door het grieks metaphysich denken hebben de christenen eeuwenlang God tegenover zijn schepping geplaatst, de christen tegenover de mens, de ziel tegenover het liggaam. de bovennatuur tegenover de natuur. de genade tegenover de cultuur, geloof tegenover vetenschap" p. 104.

Die vraag voor dic Rounsc kerk was of die kerk ..een ambielijk bediend service station voor le mensheid" is, of .het pelgrimerend Godsvolk". . soekende.. . nog sondige geloofsge. meenskap ... p. 107 - 108.

Die ekumeniese beweging is die boeiende gebeure van mekatar verrykende en korrigerende geloofsgemeenskappe. p. 110. Openbaring is die deurligting van eie bestaan as helsgebeure.

(i) A. A. van Ruler: Vragen door Bomhoffer an de orde gesteld

Mondigheid en religieloosheid kom na vore. Die problem van mondigheid kom ook voor al die ecue deur, by dic Skolastick. in die kwessie van geloof en wete. geiag en rede. Orals is daar sterk religieusiteit, in Europa sowel as in Afrika en Asië.

(j) A. A. van Ruler: Motieven en thenas in het denken ran D. Sölle

\#. . dit alles is de schukdbelijdenis. waar de tegenwoordige christenheid in zwelgt omsat ze herzenspceling van het revolutionaire marxisne heeft ondergaan" p. 139.

Hoewel Sölle e.a. verklaar dat God dood is, gaan hulle steeds nog voort met leologie, p. 140)

(k) J. M. de Jong: Is Barth achterhauld?

Nee, Barth is nic agterhaal nic. Die essensic van sy werk kom nog. hoewel sy dedukticwe. icrugmatiese en ontologiese dogmatiek tans vervang word deur die inermeneutiese eksistensiale en induktiewe, p. 143. Alle hermeneutiek is deurdring van dogmatiek, p. 147. Pannenberg stel hom teen die kritiese filo. sofie en verkondigde Woord en lee in openhid vir die Middel. eeuse Skolastick.

\section{(1) R. Schippers: R. Bultmann ent de ontmintholegisering}

Bultmann interpreteer die mites. in plaas van om hulle te elimineer. Die beste filosofie is vir hon die eksistensialisme. 
(m) A. S. ran der Woude: Ilet tweede gebod

..Het zijn van (iod laat zich niet van predikaten voorzien. wel Ciod in zijn openbarim" p. 181. ..De eigen taal van het Bybel bron van alle theologie" p 184.

(n) A. I. N. Jekkerkerker: Wuar staun wij mu?

Daar was ook in nuwe teologie in 1760 en ook in 1860. Die nuwe teologie van vandag is in protes teen die harmoniese Godsvoorstelling van in theologia naturalis uit die $18 \mathrm{e}$ eeu, p. 186.

Die groot bate van himerdie nuwe teologie is dat dit weer wil kom tot .theo-logie." Die Midde'eeue was besig met ver. wysinge na God en nie met bewsse nie. p. 188. ..De Giod-is-dood beweging is wellicht een oordeel over onze prediking van een lieve Giod. die het altiki wel goed meent met ons. Wij zullen beter moeten spreken over de heiligheid. Je verhevenheid. de verborgenheid van (jod" p. 191.192.

In plaas van (jod. wat is (ontologie). is (jod gevind (eksistensieel) maar as (jod wat ons voor is. Dit rocp tot eksodus uit die bestaande strukture, p. 193.

Die nuutste teologle is die heilshistoriese. wat eksegese en dogmatiek verbind. p. 193 en 194.

\section{(o) Scumbutting}

Ons het bostaande aanhalings hier weergegee om aan te toon dat ons ook by die molerne. sg vernuwingsteologie. hoegenaand geen enkelvoudigheid of eenvormigheid of eenlynigheid vind nie. ()ok hier is dit omtrent onmontilik om te generaliseer en alles onder een noemer te probeer kry.

In hierdie verwarde en byna verwilderde toestand. het die Skrifgelowige wetenskap sy taak en roeping. en is dit daarom des te meer noodsaaklik on vir homself duidelikheid en koers weer te vind, sodat hy homse!f nie verteer in in vrugtelose en sondige burgeroollog nie. Dic teologie van vandag mag nie naderhand soos Nero viool speel terwyl Rome brand nie. aller. mins die Skrifgelowige teologie. Dit moet sigself ueer vind. en wel in verhouding to die Skrifgelowige filosofie en die Skrif. gelowige vakwetenskappe.

Dit is des te meer noodsaaklik en dringend. nie net terwille van die (alvinisme self nie. maar omdat uit bostaande aanhalings dit baie duidelik na vore $k \mathrm{~cm}$ dat. nie net in die Middeleeue me. maar randag ook teologie en filosofie by in elk en in ieder deurmekat gestrengel is en totaal vervleg. selfs by die mense wat dit die heftigste sal ontken. Hulle is sg. anti-metafisies. maar bedoel eintlik dadrme: ek verwerp jou metafisika en stel my eie in die plek daarvan. ler illustrasie die volgende van Aristoteles."..Thought thanks itself as object in virtue of participation in what is thought. (ioll is thought. (jod is those truths which are free from change and that is these which he thinks. The highest of the virtues is, however. theoretical wisdom. and this 
is an activity of which man is capable because of something divine in his nature... in its exercise he approximates to the life of God; and for man as for God his highest function is thought". Vergelyk dit met $M$. de Jonge se weergawe van Ebeling en Fuchs in verband met teologie as hermeneutick. (D) (iii) (f) hierbo).

\section{KRITIEK OP DIE STEIIINGE IEN KONKIUSILS GEGEE IN A.}

\section{(a) Wat is Skolustiek?}

Van alle kante hoor ons vandag dat die Skolastiek en sy metafi. sika die dooJ in die pot is wat ciie teologie betref. Van der Walt werk dit nou volledig uit in verband met Thomas. dic auctor primarius van die skolastiek. Dit is totaal eensydig en onhistories. Net so min as wat ons al die soorte moverne leologic. wat onder $B$ (iii) hierbo korlliks weergegee is uit "Revolte in de Theologie". oor een kam kan skeer. netso min kan alles wat skolastiek heet onder een noemer gebring word.

H. Bavinck sê: ..Skolasliek is op zichzelve niets anders dan wetenschappelijke theologic $\mathrm{Zij}$ begint uiar de Theologia positiva cindigt. Dese is tevreden als zij de dogmata heeft uitgesproken en bewezen." Dit het te doen on die samehang te bestudeer en die Jogma te verdedig. Anselmus begin die skolastiek. maar is ook vader van die latere spekulasie." Aan die einde van die sestiende ceu begin die Gereformeerde skolastiek.

Hier is cius twee kandidate vir die eerste posisie in die Skolastiek. Wat egter van deurslaggewende belang is, is dat daar tus. sen die twee aanspraakmakers 'n radikale verskil van standpunt be. staan. Op sy grofste kan ons dit duidelikheidshalue stel dat Anselmus aansluit by in voortbou op Augustinus se ..credo. ut intelligam" terwyl Thomas se standpunt, veral wat sy natuurlike teologie betref. gestel kan word as: .. Intelligo, ut credan " "s. Hierdie radikale ver. skil word deur min opgenmerk. Solat Thomas se gixlsbewyse en Ansel nus se sg. ontologiese Godsbewys oor een kam geskeer word. Brün. mer vestig die aandag op Barth se uiteensetting in die verband. en veral sy konklusie dat Anselmus se sa. ontologiese hewys eintlik geen bewys is nie, dit is slegs in uitwerking en bevestiging van die geloof. Anselmus begin met in gebed en sluit af met die volgende ge. bed: ..I thank thee. good Lord. that what I first believed because of thy gift. I now know because of thine illumining in such a way that even if I did not want to believe thine existence, yet I could not but know it" p. 170.

R. E. Allen en E. R. Fairweather'-1 sê dat dit Anselmus se doel is ..to demonstrate the logical coherence of the Christian faith." . . . ..From start to finish. his speculative thought is an analysis of the logical structure of the Christian falth, rather than an altempt to discover religious truth by philosophical argument" ispekulaticf beteken hier redenerend, nie grensoorskrydend nie). 
Selfs themas erken dat die teenstander uileindelik slegs deur die outoriteit van die Skrif oorweldig kan word (vgl. A xiii hierbo): hoeveel te meer nie die skolastici wai die lyn van Anselmus gevolg het en nie dié van Thomas nie. Die Gereformeerde dogmatiekhand. bock vir die $17 \mathrm{e}$ ceu, die Sinopsis Purioris- gee wel 12 hewyse ten opsigte van die H. Skrif as Woord van God (p. 46). maar stel dit baie duidelik dat dit in Anselniese gees verstaan moet word. en nie Thomasiaans nie. Die Skrif self is en bly self die fınale reël van die geloof. presies soos S.C.W. Duvenhage in ons tyd dic outopistie en gesag van die Skrif handhaaf. ${ }^{3}$ Hj sê: ..Mcer relevant sal wees on af te steek na dic kern var die saak en by wyse van die dedukliewe metorle. soos in dic reël gebruik in die Reformatoriese Teologie. te gaan vra wat die Heilige Skrif self leer aangaande sy gesag ... Geen poging sal dus aangewend word on op skolastiese wyse met in formele opvattung. afgesien van die inhoud van die Skrif. voor "n dag te kom me" p. 8 . As hy hier praat van die dedukliewe metorle dan skyn dit ons dieselfde te wees as dié van Anselmus; as hy skolastiek verwerp onclerskei hy nie die twee soorte skolastick nie, maar bedrel hy waarskynlik die Thomasiaanse. wat met sy natuurlike teologie buite en sonder die Skrif opereer.

As Van der Walt dan Skolasilicse invloed by (iereformeerde teoloë meen te vind. dan moet hy batie duidelik en skerp onderskei tussen die twee soorte skolastick van Thomas en Anselmus. Dit docn hy ongelukkig nie. Daar is nog meer soorte. bv. dié van Duns Scotus. met sy primaat van die wil. .Zij brengt voor lem een scherpe scheiding teweeg tussen geloof en weten. autoriteit en rede. theologie en filosofie. De theologie verliest haar karakter van speculatieve wetenschap. Alles rust bij har op autoriteit. op Gods vrije bepaling die geen enkele noodwendigheid. door des mensen rede te ontdekken. kent. op aparte, individuele beschikkingen. die elk systematisch verband tarten. Daarom wordt de theologie vetlaagd tol een praktisch wetenschap." $=$

Het ons hier nie die eerste voorloper van Kant nie met sy skeiding van teoretiese en prakticse rede? $H$. Bavinck ste Kant se kenteorie het daartoe gelei dat die teologic. on wetenskap te kan bly. die ..kennisse Gods" moes prysgee en dit omruil vir die wetenskap van die godsdiens." Hierteenoor stel Bavinck: ..Cool te kennen is het leven."

As Van der Walt en Taljatrd (jod onkenbalar stel en Popma die teologie herlei tot geioofsteorie. hoewel hy dit skerp onderskei van die normlose godsdienswetenskap (vgl. A (c) hierbo). kon die vraag onwillekeurig by ons op: het ons nic ook hier skolastiese inviode. en wel dié van Duns Scotus nce, of iets van Kant, in albei gevalle met beklentoning en waardering viln die fell dat dit steads bly op die grondslag van die volle aanvaarding en handhawing van die Woord van God in sy gesag. hoewel nie.wetenskaplik of voorwetenskaplik.

Ien slotte kan ons hier die vraag stel of ons nie alle skolas. lick in elk geval moet uitgoni nie. afgesien daarvali of dit dié 
is van Thomas of dié van Ansclnus if dié van Duns Scolus of enige ander. As ons dit sou doen is alle wetenskaplike teologie tot niet, soos ons later sal probeer aandui. Ons kan hier al net noen dat Aristoteles se logika reeds meer as $24(x)$ jaar standhou. onveranderd en volledig. Hoewel dit deur baie ander logika's al aangevul is. kon dit nog nooit vervang word as formele wetenskaplike apparaat. wat nodig is in sekere afdelinge van die wetenskap. nie. Ook hierdie onderskeiding moet baie duidelik gestel word. nl. dat mens Aristoteles se formele logika kan en moet gebruik. sonder om sy teologie of filosofie verder te aanvaar. As mens skolastiek in die ruimste sin wil opneem. en dian uitskakel, dan moet jy ook hierdie formele logika weggooi. As jy dit nie wil doen nie. moet jy duidelik sê wat jy met skolastiek bedoel en wat jy wil weggooi en wat nie.

(b) Wat is die krag van die Evangelie in die stryd met die heiden. dom?

Vanaf die verskyning van Prof. D. H. Th. Vollenhoven se .,Het (alvinisme en de Reformatie van de Wijshegeerte" in 1933. het dis manne van die Wysbegeerte van die Wetsidee geweldige vordering gcmaak op pad na 'n volledige (hristelike of Skrifmatige wysbegeertc. veral deur die antitese mel die heidendon so skerp te stel en daarby te wys op die gevare van die sintesefilosofie.

Dit is o.a. gedoen deur baie skerp te let op die geskiedenis en betekenis van woorde en die begrippe deur hulle aangedui. Konsekwent is probeer om alles. wat van heicense oorsprong en inhoud is. uit te suiwer en nie meer te gebruik nie. So het Van der Walt bv. sekere bedenkinge teen die woord Drie-Eenheid en Popma teen die woord persoon (vgl. A (a) (vii) hierbo), in albei gevalle nie bloot ondat dit nie in die Skrif voorkom nie. maar vanwee die inhoud wat bots met die gedagtegang van die Wysbegeerte van die Wetsider". Tog is dit woorde wat deur eeue in die belydenis van die kerk ge $y \mathrm{k}$ is en wel op grond van die gedagte dat sulke woorde nodig was om die Bybelse gedagtegang Juidelik en suiwer weer te gee. veral teenoor ketters. So vra Calvyn: ..Maar wat is er tegen om dingen. die in de Schriften voor ons begrip ingewikkeld en moeilijk zijn met duideliker woorden uit te leggen, maar toch met woorden. die vromelijk en getrouwelijk de waarheid der Schrift zelf dienen. en dat spaarzamelijk en bescheiden. opdat ze te juister gelegenheid gebruikı worden"" ’: Hy sê dit juis oor dis gebruik van die woorde Drie-Eenheid en Persoon.

In die briewe van Paulus sien ons dat heidense woorde en be. grippe ook onder leiding van die Heilige (jees ..gekersten" kan word. bv. vlees en gees. Hoewel ons die konfessie natuurlik nie gelyh aan die Skrif wil stel nie. Is dit tog die vraag of dit nou noxdig is om woorde weg te gooi bloot vanweè hulle iroër heidense assosiasie. en dit met die gevaar van verwerping van die eeuelange Christe. like inhoud. Dit skyn ons of die algemene strekking van Van der Walt en Popna se betoog op sodanige verwerping neerkom, met die 
gevolg dat bv. ook die formele logika van Aristoteles as syn.le van heidense oorspiong verwerp moet word en daarmee saam die ..deduktiewe metode. soos in die reël gebruik in dic Reformatoriese Teologie", soos S. (". W. Duvenlage dit noem. ${ }^{33}$ In die algemeen skyn dit vir ons of Van der Walt die heidense element by Thomas as te sterk sien en stel, en dat hy te nin die onkeerbare krag van die Evangelie crken. ook in die denke van die mens. Hierdeur kom hy in dic versocking om (iereformecrile teoloë en andere te maklik te ver. oordeel op die klank en geskiedenis van in woord af. sonder inagname van die huidige verband waarin daardie woord gebruik word. So kan ons bv. Comarus ook beskuldig van natuurlike teologie in die sin van Thomas. terwyl hy dit $10 \mathrm{~g}$ anders beloel en praat van geopen. busurde natuurlike teologie. wat in die mens ingelê is. voor die sondeval. Deur die sonde het. volgens hom. die bo-natuurlike teologie noodsaaklik geword. ${ }^{3-}$

As ons die krag van die Evangelie nie onderskat nie. dan sou ons miskien daartoe kom om die Wÿbegeerle van die Wetsidee alleen nic as eerste poging tot in (hrivielike wyshegeerte tc verhef nic. maar on (hristelike filosofic moontiik ook by "n man soos Augus. tinus en een soos Anselmus te vind. of dan in elk geval suiuer Christelike teologic. wat nic verkrag is deur heidense filosofie nie. Dan kan ons moontlik ons aanloop vir 'n suiwer (hrostclike teologe verder terug vind as by Calvyn. wat by uitstek apologeet en ekisegeet en nie soseer sistematikus was nie. bv. Augustirits en eintlik by Anselmus. waarvandaan dic lyn oor die $17 \mathrm{c}$ ceuse Gerefor. meerde skolastick en kuyper en Bavinck tot by ons kom. Dan hoef ons die teologie nie te ont-wetenskaplik nic. of heeltemal van voor af daarmee probeer begin. soos somnige van die moderne vernuwingsteoloe. soos behandel in $B$ (iii) hierto.

Waar die belydenis vir Van der Walt ook van groot belang is. is dit miskien goed om te beklemtoon dat wat ons hier probeer stel. herus op die aanvaarding en loepassing van die (iereformeerde leer van die algemene opentaring op grond van art 2 van die N.G.B. Die vraag of ons daarmee nie tog weer tot een of ander vorm van natuurlike teologie kom nic. behandel G. (. Berkouwer volledig in sy ..De Algemene Openbaring" (vanaf p li)" Hy beantwoord die vraag met in baic besliste. nee.

\section{(c) Wat is kemmis en wat is kenhaur?}

In A (a) (v) sê Van ter Wall: .. (iod is egter dic onkenbare". ()m ons hiervan volledig rekenskap te gee. het ons in $A$ (b) etlike tellinge van Taljaard aungshaal. wat ons vir ons doel hier soos volg kortliks kan opsom.

(i) Kennis is ondarskesbatarneid en in aile kemnis is die ontiese verteoretiseer:

(ii) (iod het nie deel aan onderskeibaarheid, wat tipies aards is nie, en is daarom die Onkenbare; 
(iii) God openbaar Hom wel in Woord en natuur. Wat die Woord betref: as openbaringsinhoud wat van die Onkenbare kom. val dit ook onder die onkenbare;

(iv) die Woord van God is die waarheid. Wetenskap soek na waarheid. Omdat nie na die waarheid van die Waarheid gesoek kan word nie, is die Woord hierom ook verhef bo alle wetenskaplike ondersoek.

Waar die teologie as weteriskap tradisioneei die kennisse Gods. wat deur die Woord tot ons gekom hel. of/en die Woord van God self as veld van ondersoek gehad het, verval, volgens Taljaard se stc. linge. albei omdat hulle onkenbaar is. Hiermee verval die tradisionele teologie as wetenskap, en moet ergens anders 'n plek gesoek word vir 'n nuwe teologiese wetenskap, soos Popma dit bv. in 1946 in die geloofsteorie gevind het. . Wetenskaplike aktiwiteit is in menslike aktiwiteit en tot die wet en die kosmos beperk" .. Van der Walt, soos reeds aangehaal in $A$ (a) (v).

Hier sny nou twee dinge in mekaar, nl. ten eerste die welhe. hokende onderskeiding van die Wysbegeerte van die Wetsidee. nl. drie soorte syn soos Van der Walt Jit noem: God, wei en kosmos; ten tweede 'n betreklik onbekende en soms onopvallende definisie of bepaling van wat kennis en kentaarheid is. Laasgenoemde vind ons vollediger by Vollenhoven " soos volg: ..Kenne is dic hê van kennis, dus die verkeer in 'n toestand van rus. Hierdie toestand van rus volg op die toestand van grcler of minder inspanning waar. tydens 'n mens , leer ken'. Die veronderstellinge van clic leer ken. 'n Mens leer alleen dan iets ken wanneer ' $n$ bo-psigies goed onder. skeie van die onderlinge verskil gepaard gaan met die besware, her. innere, orden, ensovoorts van die onderskeidinge wat jy te vore geken het. By hierdie proses is dus veronderstel:

1. Die verbonde wees onder die wet van God met die liele kosmos.

2. Die onderworpe wees aan die analitiese en bo-analitiese wette.

3. Die aktiwiteit van die leer $k \in n$.

4. Die kenbare.

5. Die Kenresultaat.

6. Die verwerking van een en ander.

(Kursivering van my, DM.) Dooyeweerd prdat van sin-verbindende en .onderskeidende denke wat tot teoretiese klatarheid bring. "1

(Die verskil tussen voor- of nie-wetenskaplike kennis en weten. skaplike kennis laat ons hier buite rekening. Ten eerste omdat dit nie duidelik is of Taljaard die ontvange van die openbaringsinhoud, die Woord, ook as kennis beskou nie: hy sî̀ bv. die religie behoorı nie tot die terrein van die kenbare nie. maar dan tog weer ., die kennis wat ons hiervan het is voor-wetenskaplik" (A (b) (iii) hierbo): ten tweede omdat dit hier, in die bespreking van die veld van ondersoek vir 'n wetenskaplike teologie. nie saak maak nie. Die aangehaalde 
ontlaling van kennis van Vollenhoven geid ook vir die nic-weter: skaplike kenne. As hy oor wetenskaplike kenne handel sê hy net: ..Die wetenskaplike kenne steun orals op die nie-wetenskaplike. . . . Ons onderskei dic wel. en vakwetenskaplıke kenne."" Maw. geen definisie van wat wetenskaplıke kenne is nie. slegs die verband met die nie-wetenskaplike en die incieling in vakwetenskaplik en nie-weten. skaplik. By lg. ressorteer die wysbegeerte en ook die pedagogiek. Almal bou egler op dieselfue grondbegrip van kenris as onderskeiding, ens.)

Hierdie twee dinge wat inmekaar sny en die grond onder die tradisionele teologie wegsny. kom daarop neer dat ons denke en wetenskap, die getalle en die logiese. ailes onder die wet is. cil daarom nie by God kan kon nie omdal $\mathrm{Hy}$ bokunt die wet is. (Ons bedoel bo en onder hier hocgenaand nie ruimtelik nie.) Omdat God buitekant die bereik van ons Jenke en wetenskap is, is Sy Woord ook daarbuite. en kan dit eintlık slegs as norm van ons denke geld, maar nooit as veld van ondersoek nir. Slegs ons interpretasic daarvan kan wetenskaplik bestudeer word.

(litgaande van cenvoudige (voor-netelıskaplike) Skriflesing. die metode deur Taljaard genoen. walardeur ons ons moet vergewis van die openbaringsinhoud wat God aan ons gegee het, stel ons ons kritick hierop soos volg:

(i) Ons aanvaar ten volle dat die Woord ons baie duidelik leer dat Skepper en skepping nooit vereenselwig of vermeng niag word nie. maar steeds baic duidelik en skerp onderskei moet word. maar kan nie sien op watter Bybelse grond hier die wet juis alleen as ..grens" gestel word. Die Wysbegeerte van die Skeppingsidee van Prof. Stoker en dié van die Openbarings. idee lyk vir ons net so Bybels. Dit ; kyn vir ons of die keuse van die wet 'n blote filosofiese. en daarom in Bybels-willekeurige is, en daarom onwettig beperkend vir die wetenskap in sy veld van ondersoek. Die grense van ondersoekbaarheid word hier nie ..spekulatief" oorskry nie. maar die veld van ondersoek word on Bybels-willekeurig beperk. Waarom nie in Christelike wysbe. geerie van wets. skeppings. en openbaringsidee nie? En miskien nog meer uit die rykdon van die Skrif."

(ii) Die Bybel leer ons baie duidelık dat God die onkenbare is. in dié sin dat die menslike begrip Hom hoegenaamd nie kan peil en onvat nie. selfs in Sy Openbaring aan ons. Tergelykertyd leer die Bybel ons ook dat ons God kan ken en moet ken. Ons dink hier aan tekste soos Spr. 2:5: Jesaja 11:9; Hosea 6:6. e! veral Joh. 17:3. As ons kennis beperk tot onderskeibaarheid. wat ook ' $n$ blote filosofiese beperking is sonder enige Bybelse grond. dan mag miskien hierdic tekste nie geld nie. Maar is kennis nie veel meer as net analise of onderskeiding nie? Leer die Skrif ons dit nic. sowel as die geskiedenis van die kenteoric?

Al sou hierdic kennisse (jokls dan net voor-wetenskaplik wees. dan kan ons nic sien waarom dit dan nie die basis 
van wetenskaplike kennis mag word nie. Die kerk bely ook hierdie kennis. o.a. in art. Il N.G.B. en Christus self leer ons om elke dag te bid vir die vermeerdering daarvan: ..l aat l Naam geheilig word". soos veiklaar in Sondag 47 van die Heidelbergse Kategismus. Hierby besef ons baic goed, dat hierdie kennisse Gods. hetsy wetenskaplik of nie. nie kultuur kan wees nie. d.w.s. nie beheersend nie. soos die kultuuropdrag lui in Gen. 1:28, maar dienend en verheelikend. 'n voorsmak van die kennis van God op die nuwe aarde, na die oordeelsdag.

(iii) Alles hang hier af van wat ons met wetenskap bedoel. Taljaard sê die wetenskap soek na waarheid. en kan dus nie soek na die waarheid van die Waarheid, die IVoord van Ciod, nie. Dat die wetenskap na waarheid sock, mag waar wees, maar dit beteken hoegenaand nic. dat dic navorser ooit gaar soek na dic waarheid van die Waarhed nie. Die gelowige navorser aanvaar die Waarheid, die Woord van (joll. en ondersoek dit dan om ryker te word in die kennis van die Waarheid. Dit is waar dat die Woord norm is van die Chrsstelike wetenskap. maar juis daarom moet en kan dit des te deegliker ondersoek word. soos Anselmus dié Ciod. wat hy in die geloof alanvaar, wil ken met "n ..noodwendige" kennis."

(iv) Uliteindelik hang alles af van waar ons dic logiese ell aritmetiese plaas. As dit wetskringe .onder" die wet is, dan kan dit nie vir God geld nie en kan Hy op geen wyse !oegenaamd daaraan onderworpe wees nie. Dan is elke locus de Deo in enige dog. matiek 'n godslastering en 'n onnodige en verbode weclde. Maar dan is die voor-wetenskaplike belydenis van die Drie.Eenheid deur die kerk ook verkeerd of/en onnodig.

Ons moet ten volle toegec dat dit korrek en onweerlegbaar geredeneer is volgens die uitgangsunt(e) var, die Wysbegeerte van die Wetsidee. Dit is ook heeltemaal korrek on te handhaal dat Ciol aan geen skeppingswet onderworpe genlak mag word nie. maar ook net so min aan een of ander ander wet. buite en bokant die Skepping in ook buite en bokant $\mathrm{God}$ self

Is die fout van die Wysbegeerte van die Wetsidee nie daarin geleë. dat hy lóg vanuit die kosmos dink en redeneer. en derhalwe. heeltenaal tereg. met sy denke nie tot by (iod kan kom nie? Dit is in magtige verbetering op al die wysbegeertes wat hulle arche binne. in die kosmos gesoek het. of wat (jod en kosmos verwar of vermein: het. Daarom is, o.a.. die Wysbegecrte so vrugbaar en hevrydend vir die vakwetenskappe: hy verlos hulle van hulle ismes, hulle goxljies binne-in die skepping en stel hulle oop vir die Waarheid van (iod. sodat hulle ook tot wetenskaplike widrheid kan kom. Dit is egter nog nie genoeg of ver genoeg nie. Die wet as arché is nou wel nie in die kosmos nie. maar in sekere sin ..lussen" (ioxl en kosmos. Moet ons nie ons arché in Gol self vind nie. ook in ons wetenskap. soos dit heerlik uitgejubel word deur Paulus in Rom. 11:33.36?" (Ons kan 
natuurlik nie by hierciic Arché kom sonder Sy openbaring nie. mildr as ons die openbaring volledig aanvaar. dan moet ons Hom aanvaar as (jod Drie-Enig. soos Sondag 8 van die Heidclbergse Kategismus so eenvoudig en finaal bely. afgesien vall walter woorde of terme ons daarvoor gebruik. Beteken dit nie dat die getal. die aritmetiese priniêr in Cod self is nie. of dat Hy die wortel is daarvan. netsoos die Logos self God is en daarin die worlel en arché van die alardse logiese gevind moet word?

Dit is noeilik on hier suiwer te formuleer sonder om dalk te ketter of te ...spckuleer" (in die sin van Taljaard en nie in die sin Anselmus nie). maar die hoofsaak is dit: ons noet by God begin. ook in ons denke en wetenskap. Die ongelouige wetenskap en sells die natuurlike teologie van Thomas begin in die kosmos en probecr by Gol uitkom. Die korreksie hierop is nie voldoende as ons net die wet as ..grens" tussen (jol en kosmos gaan stel nie. Dan kom ons tog weer onwillekeurig by die Skolastiek van Duns Scotus uit, en dalk selfs by Kant (Ons moet by Goll self begun. by die argetipiese kennis van (iod self. van die Heilige Drie.Eenheid. waar Vader, Seun en Heilige (ices op goddelike wyse mekaar omderskei en liefhet. In die $\sin$ is laar dus by (jod ook onderskeibaurheid. hoewel geen aardse onderskeibaarheid nie. Soos dic mens na die beeld van God geskape is. is sy kennis ook in beeld van die kennis van (joul. ook kennis van Gorl. Hierdic is ektipiese geopenbaarte kennis. soos ons dit in die tradisionele skolastiese Gereforneerde teologie altyd nog gevind het.

M.a.w. die Wysbegeerte van die Wetsidee is 'n gewekdige vooruitgang op die nie-Skrifmagtige filosotie en ook op bale ander pogings voorheen tot Christelike filosofie. Dit het ver gegaan. maar nie ver genoeg nie. en daarom brand dit vas by die probleem van die Christelike teologie. (Om dit reg te stel. moet ons nie die Wysbegeerte van die Wetsidee verwerp of verketter nic. maar dit aanvaar en uitbon volgens die Skrif, met die nodige korreksies.

\section{I). KONKIUSII: ('IRISILIIKL TEOIOC;IE EN CIHRISTEIIKE WYSBECIEERTE.} gee. $\mathrm{nl}$.

Hier moet gepoog word om op minstens vier vrac antwoord te

(a) Wat is wetenskap! (Noodsalahliklicid van in Christelike welenskapslecr)

(b) Is ('hristelike leokngic moontlik? (Indier. wel, hoe?).

(c) Is (hristelike Itosofie nood hadklik?

(d) Wat is die suiwere verhouding tussen (hristelike Teologie en (hristelike I llos, fie"?

(a) Wut is wetenskup." Nondsuaklikheid ran 'n chriselike weten. skespleser

Dit is opvallend dal vandag in byna alle vakke cenrou. die veronderstel word dal data so iets as wetenskap is. sonder om enige verklaring of definisic datarvan te probeer gee. Dit staan 
in skrille kontras met die tradisionele teoloë. wat minstens van hulle eie vak probeer rekenskap gee het, meestal in 'n betreklike lang en deeglike inleiding. Tereg wys van Riessen op die gevaar van wetenskapsdwingelandy wat verwoestend op die kerk inwerk, netsoos Popma geweldig te velde trek teen die oorskryding van grense deur die teologiese wetenskap. meestal onder die leuse dat die teologie die koningin van die wetenskappe is

Van Riessen wys daarop dat selfs $n$ gelowige. soos Kuitert. eintlik die Skrif vernietig of kragteloos maak met in inuitgewerkte ..teologiese teorie".". . Warineer aldus: de zeketheid van het geloot onopgemerkt plaats maaht voor de zekerheid der wetenschap, zal het geloof ook de onz:kesheid en betreklikheid der wetenschap gaan delen en een speclbal worden van clke nieuwe teorie" p. 77. Dit sien uns in kuitert se bekende werke ${ }^{13}$, waarin hy min of meer saam met die meeste vernuwingsteoloë net negatief stel dat hy antimetafies en anti-skolasties is. en in sy geval dan onder die naam ..hermeneutiek" sy welenskapsleer gec. Hoedat die Wysbegeerte van die Wetsidee dit op 'n ander manicr doen. het ons probeer aandui. Eienaardis, bynt, dat juis 'n natuur. wetenskaplike. Dr. S M. Naude probeer om hom bewus rekenskap te gee van die natuurbeskouing deur die eeue heen. Hierteen. oor skyn dit of die moderne teologie kannibalisties besig is on sy eie op te vreet. hetsy deur te sê daar is geen God nie of (iod is dood, of deur die gesay van die Skrif te ontken of te onder. myn. Geen wonder dat filosofie. soes $V$ an Riessen en ander manne van die Wysbegeerte van die Westidee liewers maar veiligheidshalwe die teologie en Skrif in die voor-wetenskaplike lewens- en wêreldbeskouing plaas. $\mathrm{Al}$ is uns baic dankbaar vir die feit dat hulle die gesag van die Skrif as norm vir die weten. skap wil handhaaf. glo ons nie dat dit nodig is om dit uit die veld van ondersoek van die wetenskap te haal nie.

Dit toon Prof. Stoket baie vollediy en duidelik aan in sy aangehaalde werk." Behalwe die groot aantal geskrifte van Calviniste. meestal in verband met dic stigting en bestaan van dic Vrye ('niversiteit. Amsterdam en die P.ti. vir C.H.()., wat alnal worstel met die probleem van in (hristelike welenskap. is die werk van Stoker die volledigste en as geheel. sover ons bekend, die enigste oor die hele on!erwerp. (Ons veroncierstel bekendhei.J daarmee. en wil hier net stel dat dit tot 'n baie groot mate voldoen an die behoefie van in Christelike wetenskapsleer. Dit dek alle wetenskappe en gee bymekaar wat tot sover nog meestal versteek was in inleidings to besondere wetenskappe hier en daar.

Wat ons hier ten sterkste wil heklemtoon is dat in Chris. telike wetenskapsleer noodsaaklik is as aparte vak, apart teen. oor wysbegeerte, teologie. vakwclenskap, Bybilkunde en lewens. en wèreldheskouing. As veld van ondersoek het dit die wetenskap as geheel en op sigself en as aparte dissipliene, sal dit dic iwis oor wie die baas moet wees. fiksofic of teologic, positief oplos. 
Net so min als wat die teologic. as so. koningin van die welen. skappe. die veld van ondersoek vir die ander welenskappe kan afbaken. net so min kan die tilosutie dit doen. As hy dit probeer. soos die Wysbegeerle van die Wetsidee, dan loop hy hom lieflik vas. soos ons probecr aandui het, in die voorgaande. Slegs in in selfstandige wetenskapsleer. soos Stoker ons dit probeer gee. kan die rykdom en veclvuldigheid var die wetenskapgebou toi sy reg kon. sonder imperialisne van een of ander wetenskap of metode. Die grondslag hicrvan moet dan ook sees die onvoorwaardelike aanvaarding van dic Skrif. in sy outopistic en allesomvattende openbaring. oor beide (iod en k:smos. saam met die algemene openbaring. die openbaring van God in die natuur. soos bely in art. II N.(i.B. Vanself is hieriny ingesluit de voor.wetenskaplike kerklike belydenis. want nienand begin met wetenskapsbeoefening voordat hy nie al grootmens is nic en reeds in sy kerk belyde. nis van geloof afgele het. Hierdie wetenskapsleer sal ook nie as baas oor die ander wetenskappe heers, maar in vrughare wissclwerking met hulle voort ontwikkel. Ook hier is die vraag. wie cerste of grootsle is, onsinning en onchristelih. soos ons lecs in Matt. 2():25.28 en elders. Waar die wetenskap self die ve!d van ondersoek is van clic weteinskapsleer, sal en kan hy gedy saam met die groei van die wetenskapsgebou self.

Waar die naam I Iniversiteıt oorspronklik gesien het op dic universeelheid. waarna gestreef is met dic tradisionele aantal fakulteite. Jaar meen ons dat hierdie universeelheid nie by vie teologie tuishoort nie. ook nie by die filosifie nie. nog minder by een of ander vakwetenskap. maar by dic elementêre wetenskapsleer self. Een of ander piek moet. on: dit so te sê, iemand of in dissipline, oor homself besin; die regte plek skyn vir ons te wees so in wetenskapsleer. wat nie heersend nie. maar dienend moet uitstryk en uitpluis. wat vir elke wetenskap en vir alnaal gesamentlik nodig is. By elke vak kom dan hierby sy eie spesiale metodelogie. Ons meen dat Prof. Stoker se werk tans hierin die allerbeste is en tot $n$ groot mate voldoen aal. die behoefte.

(b) Is Christelike Teologie monnlik? Indien wel, hoe?

Op die cerste vraag het ons alreeds ja gesê. op die tweede ook gedecltelik, in die woorde van $S$. C. W. Duvenhage $\mathrm{nl}$. ..by wyse van die Jedukticue mitode. soos in die reel gebruik in die Reformatoriese teologie.". .3 Dit. sou ons sê. is die goveie" skolastiese metoxle. nl. dié waarvan ons die grondslag by Anselmus kry. Dit word soos volg beskryf:" .A characteristic of medieval logic was its mela-linguistic formulation as a quasi-prescriptive systematiation of the syntax Hat semantice of natural language " nl. Skolastiese latyn. Dit hou verband net of is verwant aan die logika van Aristoteles. die Stoiesyne. die Megarici en ook die moderne linguïstiek. Die het later verval, ontaard en steriel geword en die skolastick metlertid ten onregte $n$ skeliaam gemaah. Ook hier mag ons nie de kind met die badwater weggooi nie. 
en moet ons ons ook goed rekenskap gee van wat in die moderne tyd aangaan.

In die eerste plek moet ons dan hier let op die ontwikkeling in die modernste logika's. Ayer sè: ..Meaningful sentences either express tautologies or empirical hypotheses. but melaphysical sentences are neither lautologies, nor expressive of an empirical hypothesis, therefore they are nonsensical"." As Coot vir ons " $n$ ? metafiese Ens is, soos bv. in die natuurlike teologie van Thoma. dan is Ayer reg en het ons geen teologiese wetenskap nie. maar as dit gaan oor die openbaring van God in Sy Woord, is dit 'n gans ander saak, soos ons probeer aandur het in ..Die (iereformeerde Verbondsleer in sy betekenis vir die Sending." "hf. I. Freeman sê verder in die verband: .The present trend is to reject religious utterarces either on the ground that limitations of language do not permii us to assert them, or on the groun.l that they are incapable of verification." p. 62. Hiertecinoor stel hy in verband met teologiese waarhede: .their norm is not to be found in their verifability in Ayer's sense. but in the con. formity to the Word of GoJ." p. 64. Hier het ons eintlik te doun met een magtige groot toutologic, nl. Gol is ,.Ek is wat lik is". Dit is hiermee waarmee Anselmus eintlik besig was. .As ons egter God se openbaring aanvaur, kan ons mè vrymocdigheid toegee dat sulke kennis blote sinoniem-jsme is, mar dan is dit tog vir die :nens, met sy buperk!e verstand, nic leë sinlose pro. porsies nie. maar heerlike, volle. ryke kennis. waarsonder hy van alles eintlik niks begryp nie. Vir (jod. die wese met die oneindige intellek (vgl. die logiese positiviste soos aangehaal), bring dit totaal niks nuuts nic. want $\mathrm{Hy}$ ken alles meteens in Sy alwetendheid . . . (p. 27). . . Wat God betref is dit blote toutologie en sinoniem-isme, is die openbaring einmalig', één soos Barth tereg sê. maar vir die mens is dit 'n geskiederis in die gewone $\sin$ van die woord van eeue en nogmaals eeue, soos salamgevat in die Kanon en selfkanonisering van die Skrif (Barth) en soos nois steeds verlig deur die Heilige (jees (art. 5 N.(i.B., ens.) . . ()mdat God Drie-Enig is, en nie 'n lee metafisiese begrip nie." kan hierdie Goddelike toutologie en sinoniemisme. vir die mens die onuitputbare bron van kennis wees. wat die Kanon, onder leiding van die Heilige Gees nog steeds vir mens was en is. (Om hierdie goudmyn (Kuyper) te ontgin is lie taak van dic teologie". weten. skaplik en ook voor. en na.uetenskaplik (p 28-29).':

Ons glo dat clke mens sy eic (voor-wetenskaplike) teolo:ic uit die Skrif en Woordbediening moet opbou (volgens Sondag 47 van die Kategismus o.a.), muar dat dit ooh weterskaplik kan en moet verwerk wold. Hoe noodsaaklik dit is. blyk by B hierbo en ook uit die volgende danhalung: The Absolute is not simply one. or simply many. It must be a many in one. as correctly set forth in the Christian doctrine of the Trinity." Van Til toon ook aan hoedat Barth vasbiand in sy tcologic ondat hy nie voldoende erns maak mel die Drie.Enheid van God nic, alhoewel 
lyy baic breedvoerig daroor handel." Interensant dat Vollen. hoven sê: ..Een toutologie immers is zinloos." Dooyeweerd noem Thomas se natuurlike teologie in dogmatiese skynwetenskap (A (a) xvii hicrbo).

By hierdic dedukticwe metode, waarby die Gereformeerde beginsel van ... Sacra Scriptura sui ipsius interpres" 33 it in deurslaggewende rol speel. moet ook in aanmerking geneem word dat die ontwkketing van die histeriese wetenskappe wat na di. Middelecue gekom het. soos ook dic differensiadrekening en allerlei ntwe logika's" an . cok sy weerhlirk in die teologis gevind het en nog vind. soos bv. in die openbaringshistoriese micioles en resuliate ( $m$ dit ien volle te gebruik. hoef en mag oris nie die skolastiese deduktiewe metodes weggoor nic. Elkeen moet op sy weltige plek in die teologie gebruik word. M.a.w. die teologie kan en moet siceds vernutut word. sonder, egter. om die tradisionele waardevolle goud te verwerp. in Mooi voorbeeld van die nuwere vind ons in die .Dogmatische Studiën" van C. C. Berkouwer. Dit is nie meer tradisionele deciuktiewe dogmatiek nic. maar handhaaf tog die ouc. Opvaitend is egter dat in studie van dic Trinitas ontbreck. M.i. sal dit bly ontbreek solank as wat Berkouwer vashou aan sy defunisie van teologie as wetenskaplike besinning oor die normatiwiteit van dic Openbaring vir die ge. loof." Hierdeur verwaarloos hy tog 'n allerbelangrikste deel van die tradisionele (iereformeerde teologie.

(c) Is Christelike filosofie morelsouklik?

Al vat ons die Christelike teologic as wetenskap hoe ruim op. dan bly datar nog allyd in veld van ondersoch vir in Christelike wysbegeerte. Ter motivering hieivan verwys ons na Prof. Stoker se genoende werk. en ook lie-groolliks-daaropgebaseerde gedagtes van onsself in Ht. le van ..Verbond en sending."

(1) Wat is die suiwere verhomding mose'n Chrivelike Teologie en Christelike Hilosofie".

Hierop kan ons net sê: wisselwerking. soos uiteengesit deur Prof. Stoker. en op sy voetspoor ons gedagte vän horisontale enkaptiese struktuurvervlenting. sros uiteengesit in by. ..Verborid en Sending. .hf. le. Van belang is hier ook S. P. van der Walt: ..Die Wyshegeerle van Ilerman Bavinck". 1953 en ..Die Verhouding tussen die leologie en die filosofie by Calvyn". 1939 van I. J. M. Polgicter.

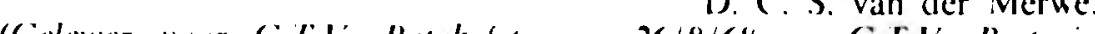

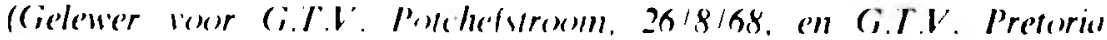
$2 .(9)(68)$

1. Vgl. N H Ridderhos oor cernuftige invalle en Sisleembou in ..D): (irtnzen der Theologie" IIncerfacultare Viordrachlen gehouden aan de Vrije Unisersileit. 1955) (ecpubliseer 1956. $>25$ 
2. W. J. de Klerk: Diktaat Flick ell logika II 1967. p. 50.

3. Vgl. K. van Wyk de Vries oor gerieflikheidmotiewe in dic verwerping of en negering van ,ou" skrywers, wal swaar, baic en lank geskryf h:l in Herwaardering van A. Kuyper se bydrae tot die (ierelormeerde Teologie noodsaaklik (In de Skriflig, nr. 2. Februarie 1967).

4. Vgl. H. van Riessen: ..Mondighesd en de Machien Christelijk Perspectief" 1967.

5. Vgl. die baic ..logika's" opgenoem en behandel deur N.T. van der Merwe in sy ..op weg na in Christelike Logika. 1958. ..The Encyclopedia of Philosophy (Ed. P. Edwards. Macmillan \& eo.. deel 4; 5). Verskillendic skrywers noem meer as 10 hoofsoorte van logika. Waarsan die van Arestoteles slegs één is.

6. D. H. Th. Vollenhoven. Soos weergegee deur J. M. Spier in ..Van Thales tot Sartre" 1959.

7. The Encyclopedia of Phılosophy Deel !

8 Anselmus soos aangchaal in $\mathrm{K}$. Barth se: Anselm Fides Quaeron: Intellect - 1960)

9. S. du Toit: "Theologie in 'n tyd van sekularisme" (In die Skriflig. Nr 4. Aug. - Sept. 1967. p. 17.)

10. In in artikel ..De Plaats der theologie, Correspondenticbladen van de Vereniging voor Calvinıstisch Wijsbegeerte. Des. 1955 en verder in hel: recks artikels tot en met 1967.

1. D. H. Th. Vollenhoven: ..Korl overzicht van de Geschiedenis der wijsbegeerte". p. 23. College dictaat Curus 1949/950 (ongepubliseer).

12. J. Hessen: Thomas von Aquin und wir Munchen. 1955. p. 24

13. W. Jaeger: ..The Theology of ihe early Giresk Philosophers 1947. p. 5 ens.

14. H. Dooyeweerd: ...De Iranscendentale critick van het theoretisch denken cu de Thomatische theologia naturalis". Philosophia Reformata 17:167 1952 .

15. „Wysbegeerte: Spekulasie of Netenskap?" K(iers. (Jg. 31 Nr. 12. Jun. 1964). Inougurele rede gelewer by $d i c$ aanvaarding van in professoraat in Wysbegeerte aan die Polchetstroomse Úniversitcit vir C.H.() op 29 Mei 1964.

16. .. Vryheid en gebondenheid in die Teologic" Kocrs. Jg. $32 \mathrm{Nr} 11$ - Mei 196.5 p. 563 .

17. ..Beginsels en metodes in die Wetenskap" 1951. p. 241

18. a.w, p. 65 en 66 .

19. a.w. p. 18.

20. ..Die (jeestelike Bevryding van die doglerkerk" in Ned. (ieref Teolugiese Tydskrif. VIII Nr. I Jan. 1967.

21. J. du Plessis: ..A History of Christian Missions in S.A." 1911. p. 40.

22. .Die (iereformeerde verbondsleer in Sy betehenis vir dic sending". 196.5 Hf. 2a en ..Die Sendinglaak in dic Lig van dic Uitverkiesingsleer" 1960) Hif. .5

23. In die versamelwerk: .. The Theology of the Christian Mission". onder redaksie van (j. A. Andersen. 1961.

24. Soos aangehaal deur bv. Andersen in ..Auf dem Wege Z.u ciner Theologic der Mission". 1958. p. 16.

25. .Trinitarian faith and today's Mission" 1964. p. 13.

26. ..Die ontwikkeling van dec menslike Natuurheskoung" - nog nic gepubliseer nie

27. Uit G. F. Callenbach, N V., Rykerk 1968

28. (j. B. Kenford oor Aristoceles in ..The Encyclopedia of Philosophy I" p. 162 .

29. ..Ciereformeerde Dogmatick" I. p. 119.

30. V. Brümmer in dikıaat van Unisa oor die Middcleense filosofic.

31. Encyclopedia of Philosophy I, p. $128+129$

32. ... Symopsis of overzicht van de Zuwerste Theologie samengeval in 52 verhandelingen en beichreven door J. Polyander, A. Rivetus, A. Walaens, A. Thysiros, doctoren en professoren der H. H. Theologie MIXXXV In de Nederlandsc taal overgezet door D van Dijk" 1964. 
33. „Die gesag van die heilige Skrif". Inougurele Iede; 14467 . Herdruk tit Koers en uitgegee deur dec iustıluut vir Bevordering van Calvinisme, P.U. vir C.H.O., Polchefstroom.

34. A. D. R. Polman in (hristeliske Encyclopedic" II, 1957, p 520.

35. .Christelijke wetenschap". p. 73 in "n .,Verspreide Geschriften" II 1902.

36. The Encyclopedia of Philosophy. I. p. 151 en verder.

37. .Institute". vertaald door Dr. A. Sizoo, Deel I. Bock I Hf. XIII, 3. 4 p. 101.

38. G. P. van Olterzon: F. Comarus 1930, p. 279.

39. By, Kok, Kampen, 1951.

40. I). H. Th. Vollenhoven: ..Inleiding in de Wysbegeerte Veruerk in Afrikaans met enkele komnentare" deur J. A. L. Taljaard. Pro. Rege. 1968 p. 111 .

41. ,.De Wijsbegeerte der Wetsidee", 1935. I p 125.

42. a.w., p. 140 .

43. H. "M. Kuikerk: ..De Mensvormigheid Gods" 1962; .De Realiteit van het (jeloof" en .. De (joede Schepping in Citoof en Wetenschap", Jrg 61 Jun-Jul. 1963.

44. "The Encyclopedia of Philosophy" IV, p. 528.

45. Aangehaal deur H. Freeman ir. .Some recent developments in Philosophical Theology", p. 58-70 in Philosophia Reformata. Jg. 27, 1962. Dil kom uit A. J. Ayer: ..Language. truth and logic" 1948.

46. Kuyper sê: Ons bestudeer nic de engekende uese ian God nic, ,maar Je ons bekend gemaakte coguitio ectypia ..Encyclopedic der H. Codgeleerd. heid" Deel I 2e druk. p. 170.

47. Verbond en Sending, 1965. p. 22-32.

48. in Breedvoerige voorbecld hiervan gec ons in noot 107, p. vii-xxiv van ons ..Sending en Uitverkiesing" Sien (22) hierbo.

49. W. T. Stace: .A Critical History of Greck Philosophy, 1928.

50. Van Til: .. The New Modernisni. An Appraisal of the theology of Barth and Brummer, 1946.

51. .Hoofdlijnen der Logika." 1948. p. 69.

52. "Wat is teologie" (p. 11) in Interlacultaire (olleges dan de Vrije Univers](cit. $1949 \cdot 1950$. 